\title{
Biotechnological aspects of transformation of heavy metal salts and their detoxication in milk of milk cows
}

\author{
Boris Dzagurov ${ }^{1}$, Oleg Getokov, ${ }^{2,}$, Vladimir Gukezhev ${ }^{3}$, Taladin Kokov², and Vitaly \\ Vorokov ${ }^{5}$ \\ ${ }^{1}$ Gorsky (Mountain) State Agrarian University, 37 Kirova str., 362040 Vladikavkaz, North Ossetia- \\ Alania \\ ${ }^{2}$ Kabardino-Balkarian State Agricultural University named after V.M.Kokov, Lenin Avenue, 1V, \\ 360030 Nalchik, Russia \\ ${ }^{3}$ Kabardino-Balkarian Scientific Center of the Russian Academy of Sciences \\ ${ }^{4}$ Kabardino-Balkarian State University, str. Chernyshevskogo, 173, 360004 Nalchik, Russia \\ ${ }^{5}$ SFEI of HPT "I.T. Trubilin Kuban State Agrarian University", 13 Kalinina St., 350044 Krasnodar, \\ Russia
}

\begin{abstract}
Based on the results of previous studies on pigs and poultry, in which encouraging results of a significant decrease in the concentration of heavy metals in the body were obtained, respectively, in pork, poultry and eggs, the study provided for the use of the bentonite clay of the Zamankul deposit (RNO-Alania) as an enterosorbent in relation to heavy metals and detoxification of the organism of dairy cows. In order to study the feasibility of using bentonite as an enterosorbent, studies were performed on dairy cows of the Simmental breed in the Kaloyev farm located in st. Zmeyskaya, Kirovsky district of North Ossetia-Alania. To conduct research on the principle of analog pairs, two experimental groups of cows (control and experimental, five cows in each group) of the 3rd and 4th lactation were formed. The experiment lasted for 305 days of lactation from March 2018 to January 2019. Herewith, the control group of cows was fed with a basic diet balanced in all nutritional elements, the experimental livestock, together with the main diet, daily in the composition of the concentrates was injected with crushed bentonite with a particle diameter of 4-6 mm based on the dry matter of the feed (137 $\mathrm{g} /$ animal). The study of the concentration of heavy metals (cadmium, lead and zinc) in soil, feed, blood and milk was performed in two periods of lactation (on the 250th and 300th days of lactation). Herewith, an increased content of heavy metals in the soil was established, relative to the MPL: cadmium - 10.1; lead - 7.4; zinc - 9.7 times more, in drinking water: cadmium - 2.5 times; lead - 9.0 times and zinc -9.7 times more, in feed: cadmium - from 1.7 to 5.3 times; lead - from 1.1 to 1.7 ; zinc - from 1.0 to 2.5 times the MPL. The inclusion of bentonite to the ration of the animals of the experimental group, in comparison with the control group, in both study periods ( 250 and 300 days of lactation) contributed to a significant decrease in the concentration of the studied heavy metals in the blood from 17 to $20 \%$, in milk - from 16 to $18 \%$. The transformation ration values of
\end{abstract}

\footnotetext{
"Corresponding author: getokov777@mail.ru
} 
heavy metals from feed into the body, respectively, into milk, were also lower in the animals of the experimental group, relative to the control.

\section{Introduction}

As known, heavy metals are considered one of the most dangerous toxicants that enter the biosphere along with the combustion products of diesel engines, industrial emissions, especially when processing the non-ferrous metal ore. Once in the human or animal body, these pollutants accumulate in muscle tissue, liver and kidneys, causing cytolysis of cellular structures and necrotic manifestations, a decrease in hematopoiesis, thereby causing a weakening of immunity, both cellular and humoral, increasing the risk of developing various pathologies, and in animals also decrease in productivity $[1,3,5,7,8,9,10]$.

The biosphere, including the soil of the Republic of North Ossetia-Alania, is contaminated with heavy metals, due to emissions of pollutants by industrial enterprises of non-ferrous metallurgy, exhaust gases from vehicles, etc. In this case, following MPL values have been exceeded: - zinc by 10 times, - lead by 8 times, - cadmium by 9 times [5]. In connection with the above, we conducted studies to study the possibility of using as an enterosorbent, in relation to heavy metals, feeding dairy cows with bentonite clay from the local Zamankul deposit, located near the village of Zamankul and the transformation of heavy metals (cadmium, lead, zinc) along the food chain: soil - plants (feed - cows' organism (blood) - milk. The studies performed are relevant due to the fact that bentonite dressings from this deposit, considering the sorbing properties, were previously used by us for the first time, as an enterosorbent for removing heavy metals from the body of pigs and poultry of the meat production direction $[2,3,4,6]$, accordingly, from a product that has established encouraging research results.

The research was aimed to study the effect of bentonite supplements (as enterosorbents) of dairy cows and their ability to detoxify and remove heavy metals from the body, respectively, to reduce their concentration in milk.

\section{Material and methods}

The experiment was performed in the farm "Kaloyev", located in st. Zmeyskaya of Kirovsky district of North Ossetia-Alania from March 2018 to January 2019.

For the research, two experimental groups of dairy cows of the 3rd and 4th lactation of the Simmental breed (control and experimental, five heads in each group) were formed by the analog-pair method. The conditions of keeping the cows corresponded to the zoohygienic regulations. The system of keeping the experimental livestock in the springsummer-autumn period was stall-pasture, in the winter - stall. The experiment lasted for 305 days of lactation, in which the control group of cows was fed a basic diet balanced in all nutrients, mineral elements and vitamins pursuant to the standards of Federal Cattle Breeding Research Center (2003) [1]. Following ingredients were the basis of the fodder ration in the winter period: meadow hay - $16 \%$, corn silage $-44 \%$, mixed fodder $-9 \%$, grain chaff - $5 \%$, grain stillage $-14 \%$, fodder molasses $-12 \%$. Herewith, dry matter contained in the winter ration of feeding amounted to $13.7 \%$. The sugar-protein ratio was $0.8: 1.1$; the ratio of calcium to phosphorus is 1.6:1.0. The summer ration of feeding consisted of: artificial pasture grass - $88 \%$, compound feed $-5 \%$, grain stillage $-7 \%$. The dry matter in the ration was $12.9 \%$. The sugar-protein and calcium-phosphorus ratios in the summer feed ration were within the recommended limits. For the experimental group, in addition to the main ration, the concentrates included crushed bentonite, with a particle diameter of 4-6 $\mathrm{mm}$, daily in an amount of $1 \%$ (137 g/animal), based on the dry weight of the feed. The 
specified amount of fed bentonite was established during a reconnaissance experiment in the same farm, in which out of three different tested levels of feeding dairy cows, the optimal dose was recognized as $1 \%$ of the dry mass of feed, at which the milk productivity of cows and the qualitative and technological characteristics of milk significantly increased $[2,11]$.

In accordance with the purpose of research and study of the transformation of heavy metals along the food chain (soil-feed-organism-milk), during the accounting periods (on the 250th and 300th days of lactation), 5 average samples of soil, feed, blood and milk were taken. pursuant to generally accepted methods. Ashing of these samples was performed in a muffle furnace at temperatures up to $500^{\circ} \mathrm{C}$ pursuant to GOST 26929-94. Ash samples were subjected to atomic adsorption analysis on an AAZ-115-M1 spectrophotometer at the Republican Veterinary Laboratory.

Herewith, the transformation ration values of heavy metals from feed and water into the body of cows, respectively, into milk, were calculated pursuant to the following formula:

$$
\mathrm{KT}=\frac{\mathrm{A} \text { milk }}{\text { A ration }+\mathrm{A} \text { water }} \times 100 \%,
$$

where TR is the transformation ratio;

A milk - the content of heavy metals in the daily milk yield, $\mathrm{mg} / \mathrm{kg}$;

A ration - the content of heavy metals in the daily diet, $\mathrm{mg} / \mathrm{kg}$;

A water - the content of heavy metals in drinking water, $\mathrm{mg} / \mathrm{l}$;

The transformation ratio of heavy metals into the body of cows (into the blood) was calculated by the formula:

$$
\mathrm{KT}=\frac{\mathrm{A} \text { blood }}{\mathrm{ACB}} \times 100 \%,
$$

where TR is the transformation ratio;

A blood - the content of heavy metals in the blood of cows, $\mathrm{mg} / \mathrm{kg}$;

$\mathrm{ACB}$ - the content of heavy metals in the dry matter of the ration, $\mathrm{mg} / \mathrm{kg}$;

Soil samples, taken to a depth of 10 centimeters, were taken in five places on the territory of the farm, where mowing and preparation of roughage, as well as mowing of green mass and grazing of cows in the summer grazing period, was performed.

\section{Results and discussion}

In the laboratory, spectral analyzes of average samples of soil, water and feed, the concentration of heavy metals, given in Table 1, was established.

From the results of spectral analyzes of the studied samples for the content of heavy metals, given in Table 1, it follows that in soil samples taken in different parts of the territory of the economy, an excess concentration of cadmium from the MPL was established - by 10.1 ; lead - by 7.4 ; zinc - by 9.7 times $(\mathrm{P} \leq 0.01)$. The content of heavy metals in drinking water was also higher than the MPL: cadmium - by 2.5 ; lead - by 9.0; zinc by -9.7 times.

Table 1. Concentration of heavy metals in the test samples, $\mathrm{mg} / \mathrm{kg}, \mathrm{n}=5$.

\begin{tabular}{|l|c|c|c|}
\hline \multirow{2}{*}{ Sample designation } & \multicolumn{3}{|c|}{ Heavy metals } \\
\cline { 2 - 4 } & Cadmium & Lead & Zinc \\
\hline HM mobile forms in soil & $2.01 \pm 0.11$ & $44.5 \pm 1.34$ & $225 \pm 2.66$ \\
MPL & 0.2 & 6 & 23 \\
\hline Drinking water $\mathrm{mg} / \mathrm{l}$ & $0.0025 \pm 0.0001$ & $0.27 \pm 0.03$ & $0.02 \pm 0.001$ \\
MPL & 0.001 & 0.03 & 1.0
\end{tabular}


Table 1. Continued.

\begin{tabular}{|l|c|c|c|}
\hline Meadow hay & $1.61 \pm 0.13$ & $8.6 \pm 0.23$ & $77.2 \pm 8.54$ \\
\hline Corn silage & $1.53 \pm 0.34$ & $7.8 \pm 0.53$ & $61.3 \pm 4.52$ \\
\hline Grain chopping & $0.51 \pm 0.31$ & $9.3 \pm 0.98$ & $58.4 \pm 8.53$ \\
\hline Grain distillery refuse & $0.55 \pm 0.42$ & $5.84 \pm 0.42$ & $52.1 \pm 3.57$ \\
\hline Artificial pasture grass & $0.77 \pm 0.55$ & $7.32 \pm 0.43$ & $63.4 \pm 4.32$ \\
\hline MPL & 0.3 & 5.0 & 50.0 \\
\hline
\end{tabular}

The content of heavy metals in the studied fodder was also higher than the MPL: cadmium in meadow hay - 5.3 times; corn silage - 5.1 times; grain cut - 1.7; in grain stillage - 1.8; grass from artificial pasture - by 2.5 times. Lead was contained in the feed used: meadow hay - 1.7 times more than the MPL; corn silage - by 1.5 ; grain cut - by 1.6 times; grain stillage by 1.1; grass from artificial pasture - by 1.4 times. Zinc was also contained more from the MPL: in meadow hay - by 1.5 times; corn silage - by 1.2; grain cut - by 2.5; grain stillage - by 1.0 times; in grass from artificial pastures - by 1.2 times.

The morphological and biochemical composition of the blood, respectively, the physiological activity of individual organs and tissues of the whole organism depends on the composition of the animal feed ration, the presence of certain nutrients in it. In this regard, in order to study the effect of feeding with bentonite, as an enterosorbent in relation to heavy metals, on the 250th and 300th days of lactation, blood was taken from 2 compared experimental groups of cows, from the jugular vein, in the morning before feeding and preserved her heparin. Herewith, the conducted hematological studies established that the content of the studied heavy metals in the blood (in the body) of cows in the control group was higher than the MPL, which corresponded to the concentration of heavy metals in the fed feed. The inclusion of bentonite as an enterosorbent in animals of the experimental group contributed to a decrease in the amount of studied heavy metals in the body of cows. The results of spectral analyzes of blood and indicators of the transfer of heavy metals from feed to the body (into the blood) are given in Table 2.

Table 2. Concentration of heavy metals in the blood of experimental cows and the transformation ration values from feed to the body, $\mathrm{mg} / \mathrm{l} \mathrm{n}=5$.

\begin{tabular}{|c|c|c|c|c|c|c|}
\hline \multirow{4}{*}{$\begin{array}{c}\text { Experimenta } \\
\text { I groups }\end{array}$} & \multicolumn{6}{|c|}{ 250th day of lactation } \\
\hline & \multicolumn{2}{|c|}{ Cadmium } & \multirow{2}{*}{\multicolumn{2}{|c|}{$\begin{array}{c}\text { Lead } \\
0.05-0.25\end{array}$}} & \multirow{2}{*}{\multicolumn{2}{|c|}{$\begin{array}{c}\text { Zinc } \\
3.0-5.0\end{array}$}} \\
\hline & MPL & $0.01-0.015$ & & & & \\
\hline & $\begin{array}{c}\text { content in } \\
\text { blood }\end{array}$ & $\begin{array}{c}\text { transf. } \\
\text { values., } \%\end{array}$ & $\begin{array}{l}\text { content in } \\
\text { blood }\end{array}$ & $\begin{array}{c}\text { transf. } \\
\text { values., \% }\end{array}$ & $\begin{array}{c}\text { content in } \\
\text { blood }\end{array}$ & $\begin{array}{c}\text { transf. } \\
\text { values., \% }\end{array}$ \\
\hline Control & $0.044 \pm 0.002$ & 1.04 & $0.29 \pm 0.003$ & 3.62 & $7.84 \pm 0.11$ & 1.87 \\
\hline Experimental & $0.036 \pm 0.005$ & 0.85 & $0.24 \pm 0.005$ & 3.11 & $6.52 \pm 0.16$ & 1.56 \\
\hline $\begin{array}{l}\% \text { of the } \\
\text { control group }\end{array}$ & -118.1 & -0.19 & -117.2 & -0.51 & -116.8 & -0.31 \\
\hline & & & 300th da & f lactation & & \\
\hline Control & $0.031 \pm 0.003$ & 1.69 & $0.24 \pm 0.003$ & 3.64 & $7.21 \pm 0.14$ & 2.06 \\
\hline Experimental & $0.025 \pm 0.006$ & 1.36 & $0.19 \pm 0.004$ & 3.12 & $5.92 \pm 0.15$ & 1.69 \\
\hline $\begin{array}{l}\% \text { of the } \\
\text { control group }\end{array}$ & -119.3 & -0.33 & -120.8 & -0.52 & -117.8 & -0.37 \\
\hline
\end{tabular}

The results of the studies given in Table 2 show that the inclusion of bentonite in the diet of cows in the experimental group, considering its detoxification (enterosorbent) properties, contributed to the elimination of the studied heavy metals from the body and a decrease in their concentration in the blood from 16 to $19 \%(\mathrm{P} \leq 0,01)$ in both study periods. A proportional decrease in the coefficients of the transfer of the studied heavy metals from the fed feed into the organism (into the blood) of animals was noted. It was found that in the first study (at 250 days of lactation), which fell on the winter period, a higher 
concentration of heavy metals was noted in the feed, respectively, in the blood of cows than in the second study (at 300 days of lactation) in the summer period of the study.

One of the factors that determine the degree of environmental safety of milk and dairy products and their use for human nutrition is the level of pollution with heavy metal salts. Partial removal of heavy metal salts from the body of animals of the experimental group in the zone with increased environmental pollution contributed to the production of relatively environmentally friendly products and the improvement of the commercial and technological properties of milk (B.A. Dzagurov, A.G. Karlov, 2020). In this regard, during the period of control milk yields on the 250th and 300th days of lactation of experimental cows, milk samples were taken from cows of the compared experimental groups and subjected to spectral analyzes for the presence of heavy metals (cadmium, lead and zinc). The analysis results are shown in Table 3.

Table 3. The content of heavy metals in milk and the coefficients of their transformation from feed into milk, $\mathrm{n}=5$.

\begin{tabular}{|c|c|c|c|c|c|c|}
\hline \multirow{4}{*}{$\begin{array}{c}\text { Experimenta } \\
\text { I groups }\end{array}$} & \multicolumn{6}{|c|}{ 250th day of lactation } \\
\hline & \multicolumn{2}{|c|}{ Cadmium } & \multirow{2}{*}{\multicolumn{2}{|c|}{$\begin{array}{c}\text { Lead } \\
0.1\end{array}$}} & \multirow{2}{*}{\multicolumn{2}{|c|}{$\begin{array}{c}\text { Zinc } \\
\mathbf{5 . 0}\end{array}$}} \\
\hline & \multirow{2}{*}{$\begin{array}{c}\text { MPL } \\
\mathrm{mg} / \mathrm{kg} \\
\begin{array}{c}\text { content in } \\
\text { milk }\end{array}\end{array}$} & \multirow{2}{*}{$\begin{array}{c}0.03 \\
\text { transf. } \\
\text { values., \% }\end{array}$} & & & & \\
\hline & & & $\begin{array}{c}\text { content in } \\
\text { milk }\end{array}$ & $\begin{array}{c}\text { transf. } \\
\text { values., } \%\end{array}$ & $\begin{array}{c}\text { content in } \\
\text { milk }\end{array}$ & $\begin{array}{c}\text { transf. } \\
\text { values., \% }\end{array}$ \\
\hline Control & $0.041 \pm 0.003$ & 1.05 & $0.13 \pm 0.006$ & 3.61 & $6.98 \pm 0.14$ & 1.85 \\
\hline Experimental & $0.034 \pm 0.006$ & 0.86 & $0.11 \pm 0.007$ & 3.22 & $5.87 \pm 0.16$ & 1.54 \\
\hline $\begin{array}{l}\% \text { of the } \\
\text { control group }\end{array}$ & -117.0 & -0.19 & -115.4 & 1) & -115.9 & -0.31 \\
\hline & & & 300th day o & ctation & & \\
\hline Control & $0.037 \pm 0.003$ & 1.51 & $0.16 \pm 0.004$ & 3.62 & $6.53 \pm 0.15$ & 1.82 \\
\hline Experimental & $0.031 \pm 0.006$ & 1.31 & $0.13 \pm 0.005$ & 3.21 & $5.36 \pm 0.17$ & 1.54 \\
\hline $\begin{array}{l}\% \text { of the } \\
\text { control group }\end{array}$ & -116.3 & -0.20 & -118.8 & -0.41 & -117.9 & -0.29 \\
\hline
\end{tabular}

The digital material presented in Table 3 shows that the addition of bentonite to animal feed contributed to a decrease in the concentration of cadmium in the milk of the experimental group of cows by $17 \%$, at the 250 th day of lactation, and at the 300th day of lactation by $16.3 \%$ at $\mathrm{P} \leq 0.01$, in relation to similar indicators of milk samples, milked from cows of the control group. The coefficients of the transition of cadmium into milk from the cows of the experimental group, in the first period of the study, are less by $0.19 \%$, in the second period - by $0.20 \%$, compared with the control.

The content of lead in the milk of the experimental group of cows decreased in relation to the control samples of milk in the first period of the study - by $15.4 \%$, in the second period - by $18.8 \%(\mathrm{P} \leq 0.01)$. In the first period of the study ( 250 days of lactation), the coefficient of transformation of lead from feed into milk of the experimental group of animals was less than the control - by $0.39 \%$, in the second period of analyzes (300th day of lactation) - by $0.41 \%$.

It should be noted that the conversion ratios of lead from feed to milk were significantly higher compared to the analogous indicators of the conversion of cadmium and zinc into the milk of experimental cows.

Zinc in the milk of cows from the control group in the first period of research (250 days of lactation) contained $6.98 \mathrm{mg} / \mathrm{l}$, in milk samples from the experimental group - $5.87 \mathrm{mg} / \mathrm{l}$, which is $15.9 \%$ less $(\mathrm{P} \leq 0.01)$. The coefficient of transformation of zinc from feed into milk of the experimental group of cows was $0.31 \%$ less than in the milk of cows from the control milk samples. In the second period of analyzes (300 days of lactation), the milk of cows in the control group contained $6.53 \mathrm{mg} / 1$ zinc, in the milk of experimental milk samples - 
$5.36 \mathrm{mg} / 1$, i.e. by $17.9 \%(\mathrm{P} \leq 0,01)$ less control milk analogues. Coefficients of zinc conversion from feed to milk in the first period of analyzes were $0.31 \%$ less in milk from the experimental group of cows, in the second period - by $0.29 \%$, in relation to milk samples from the control group.

The results of the research have established that the inclusion of bentonite in the composition of the feed ration of cows contributed to a significant (reliable) decrease in the concentration of the studied heavy metals both in the blood of animals and in milk produced, in comparison with similar indicators of control blood and milk samples.

\section{Conclusions}

1. In the studied soil samples on the territory of the farm where the research was performed, an increased content of heavy metals relative to the MPL was noted: cadmium 10.1; lead - 7.4; zinc - 9.7 times more.

2. The drinking water samples contained: cadmium -2.5 times; lead -9.0 times and zinc - 9.7 times more in comparison with the MPL.

3. In the fed fodder the concentration of the studied heavy metals exceeded: cadmium - from 1.7 to 5.3 times; lead - from 1.1 to 1.7; zinc - from 1.0 to 2.5 times the MPL.

4. In the blood (body) of cows of the control group on the 250th day of lactation in relation to the animals of the experimental group, more heavy metals were contained: cadmium by - $18.1 \%$; lead - by $17.2 \%$; zinc - by $16.8 \%$. On the 300 th day of lactation: cadmium - by $19.3 \%$; lead - by $20.8 \%$; zinc - by $17.8 \%$. Pursuantly, the transformation ration values of heavy metals from feed into the body (blood) were lower in the animals of the experimental group compared to the control in both study periods from 0.19 to $0.43 \%$.

5. Milk samples dairy from cows of the experimental group during the study periods (250 and 300 days of lactation) contained significantly less heavy metals in relation to the control from 16 to $17 \%$. Coefficients of transformation of heavy metals from feed into milk were lower in animals of the experimental group in relation to the control by $0.19-0.41 \%$.

\section{Recommendation to production}

In order to reduce the content of heavy metals in the milk produced and reduce the coefficients of the transfer of heavy metals from feed to the body of cows, respectively, into milk, feed dairy cows with crushed (bentonite particle diameter - 4-6 mm) bentonite in an amount of $1 \%$ of the dry weight of the feed, in kind $137 \mathrm{~g} /$ animal per day.

\section{References}

1. V. A. Alikaev, E. A. Petukhova, L. D. Haleneva, et al, Animal Feeding and Management Handbook, 320 (1982)

2. B. A. Dzagurov, R. H. Gadzaonov, A. G. Karlov, Bulletin of the Gorsky State Agrarian University, 57(1), 54 (2020)

3. B. A. Dzagurov, A. G. Karlov, Bulletin of the Gorsky State Agrarian University, 57(2), 97 (2020)

4. B. A. Dzagurov, Z. A. Ktsoeva, Bentonite feeding of pigs (2018)

5. V. R. Kairov, Actual problems of scientific support for increasing production, improving the quality of feed and their effective use, 165 (2001)

6. S. A. Lapshin, Chemicalization of agriculture, 8, 62 (1988) 
7. M. G. Chabaev, Journal of Pharmaceutical Sciences and Research, 10(5), 1122 (2018)

8. A. A. Baeva, Indo American Journal of Pharmaceutical Sciences, 6(9), 15992 (2019)

9. A. B. Baragunov, E. A. Kushaeva, M. M. Hamokov, A. V. Sagatelian, E3S Web of Conferences, 193 (2020)

10. A. B. Baragunov, I. A. Savvateeva , S. H. Kushaev, A. A. Kumakhov, Z. R. Kudaev, IOP: Earth and Environmental Science, 3 (2019)

11. T. T. Tarchokov, Z. M. Aisanov, S. F. Sukhanova, M. G. Tleinsheva, A. A. Mishhozhev, D. S. Balpanov, IOP: Earth and Environmental Science, 1 (2019) 